\title{
Biosorption of Malachite Green by Dry Cells of Isolated Free Living Nitrogen Fixing Bacteria
}

\author{
A.M.M. Mawad*(***)†, H. Albasri* and H. A. Temerk** \\ *Biology Department, College of Science, Taibah University, Al-Madinah Al-Munawarah, Saudi Arabia \\ **Botany and Microbiology Department, Faculty of Science, South Valley University, Qena, Egypt \\ ***Botany and Microbiology Department, Faculty of Science, Assiut University, Assiut 71516, Egypt \\ $†$ Corresponding author: A.M.M. Mawad; ammawad@taibahu.edu.sa
}

Nat. Env. \& Poll. Tech.

Website: www.neptjournal.com

Received: 19-10-2020

Revised: 17-11-2020

Accepted: 11-12-2020

Key Words:

Azotobacter

Biosorption

Malachite green

Nitrogen fixing bacteria

\begin{abstract}
Contamination of water with Malachite green (MG) may threaten aquatic and human life. Nitrogenfixing Azotobacter sp. is an efficient adsorbent for the removal of MG from dye solutions. The optimum $\mathrm{pH}$ for the biosorption process was determined. The maximum adsorption capacity and the effect of different adsorbate concentrations were detected. The kinetics and isotherm models for biosorption were constructed. Optimum adsorption of MG by Azotobacter sp. was obtained at pH 6.0, biomass concentration was $0.05 \%$, initial dye concentration was $50 \mathrm{mg} . \mathrm{L}^{-1}$, and contact time was 600 mins. Dye adsorption exhibited an increase with contact time and initial malachite green concentration. The kinetics of the adsorption process was best followed by the pseudo-second-order kinetic model which confirms the chemisorption process. The adsorption equilibrium data fit well to the Langmuir model indicating a monolayer adsorption behavior onto a surface of Azotobacter sp. with a finite number of active sites. Maximum biosorption capacity was found to be $142.8 \mathrm{mg}^{-1} \mathrm{~g}^{-1}$ of bacterial biomass. The dry biomass of Azotobacter sp. has proved to be an efficient biosorbent for the removal of synthetic dyes from actual industrial effluent that is contaminated with up to $400 \mathrm{mg}^{-\mathrm{L}^{-1}}$ dye concentration.
\end{abstract}

\section{INTRODUCTION}

Malachite green (MG) is a cationic triphenylmethane dye that is extensively used in many industries such as textile, pharmaceutical, and the aquaculture industry (Nath \& Ray 2015; Wu et al. 2020). It is used as a food coloring agent, food additive, disinfectant, and anthelminthic (Srivastava et al. 2004, Gao et al. 2017). It is also used to stain silk, wool, jute, leather, cotton, paper, and acrylic industries (Culp \& Beland 1996). Malachite green represents a major part of the total production of dye-containing wastewater in the textile industry (Nemerow 1963). The major sector of the economy worldwide mainly depends upon the textile industry; this has led to an increase in the release of large amounts of organic chemicals including dyes and many inorganic chemicals in industrial effluents and wastewater (Kumar et al. 2006).

The discharge of these pollutants in the aquatic environment may alter the chemical, physical and biological characteristics of the aquatic system (Erdem et al. 2005; Dos Santos et al. 2007). Malachite green particularly has a negative impact on the immune and reproductive systems (Gouranchat 2000; Inyinbor et al. 2020). Moreover, the US Food and Drug Administration (FAD) has nominated MG as a priority chemical for carcinogenicity investigations (Culp
\& Beland 1996). Although the use of MG has been forbidden in many countries and not FAD approved (Cha et al. 2001), it is still being consumed in other countries due to its low cost and availability (Schnick 1988).

The removal of color from dye wastewater is a complicated method due to its high solubility and low biodegradability (Gupta \& Saleh 2013). Chemical precipitation, oxidation, and degradation are commonly used for that purpose however, they are only effective at a high solute concentration (Mawad et al. 2020). The adsorption process is an effective alternate strategy for the removal of dye wastewater (Mawad et al. 2014; Mawad et al. 2016). Microorganisms play an efficient role as biosorbent for the removal of pollutants from aqueous solutions (Mawad et al. 2016). The cell surface of microorganisms has a high affinity towards charged molecules such as cationic dyes. Adsorption of dyes by dry, non-viable microorganisms is characterized by no nutrient needed for cell growth, the high removal efficiency of colored effluents, and lack of toxicity limitations (Adhikari et al. 2010, Mawad et al. 2015, Liu et al. 2018).

Therefore, the main objective of this study is to determine the efficiency of isolated nitrogen-fixing Azotobacter sp. for adsorption of MG from an aqueous solution. 


\section{MATERIALS AND METHODS}

\section{Isolation of Azotobacter sp.}

Free-living nitrogen-fixing bacteria Azotobacter sp. was isolated from cultivated soil. The isolate was cultivated on the nitrogen-free (NF) medium consisting of per liter, 10 g mannitol, $10 \mathrm{~g} \mathrm{CaSO}_{4}, 2 \mathrm{~g} \mathrm{MgSO}_{4} .5 \mathrm{H}_{2} \mathrm{O}, 2 \mathrm{~g} \mathrm{NaCl}, 2 \mathrm{~g}$ $\mathrm{FeSO}_{4}$ and $5 \mathrm{~g} \mathrm{~K}_{2} \mathrm{HPO}_{4}$ and $15 \mathrm{~g}$ agar and $\mathrm{pH}$ adjusted at 7.0. The medium was autoclaved, poured into Petri dishes and supplemented with $0.5 \mathrm{~g}$ of fine soil particles after solidification, and incubated at $30^{\circ} \mathrm{C}$ for $24 \mathrm{~h}$. The growing colonies were purified using the streaking plate method and preserved at $4^{\circ} \mathrm{C}$ for further use.

\section{Preparation of Biosorbent}

The bacterial isolate Azot-6 was selected for adsorption of dye based upon heavy growth on the NF medium. The bacterial cells were cultivated on $1 \mathrm{~L}$ of broth NF medium for 24-48 h, centrifuged at $5000 \mathrm{rpm}$ for $10 \mathrm{mins}$. The pellets were collected and washed three times by deionized water. The bacterial cells were completely dried in a vacuum hood cabinet for 7 days. The dried cells were then directly used as an adsorbent surface.

\section{Biosorption Experiments of Malachite Green}

Malachite green (MG), a synthetic basic (cationic) dye was used as a sorbent in this study. The batch dye removal was investigated in an Erlenmeyer flask $(50 \mathrm{ml})$ containing $20 \mathrm{~mL}$ of $100 \mathrm{mg} . \mathrm{L}^{-1}$ of $\mathrm{MG}$ and $0.05 \mathrm{~g}$ of bacteria. The experiment was performed at $30^{\circ} \mathrm{C}$ agitated on a rotary shaker at 150 $\mathrm{rpm}$ for $12 \mathrm{~h}$ to reach adsorptive equilibrium.

The biosorbent (dried bacteria) along with adsorbed dye then was separated from the solution by centrifugation at $8000 \mathrm{rpm}$ for 5 mins and the remaining concentration in the supernatant was analyzed using a UV spectrophotometer at maximum absorption wavelengths, $\lambda \max =618 \mathrm{~nm}$.

The calibration curve was constructed by dissolving 10$600 \mathrm{mg} . \mathrm{L}^{-1}$ of $\mathrm{MG}$ in deionized water and the absorbance was plotted against a certain concentration using a UV spectrophotometer (Deep Vision $301 \mathrm{E}$ ) at $\lambda \max =618 \mathrm{~nm}$. The linear plot equation was used to determine the remaining concentration of the solution during the biosorption process.

\section{Effect of pH Values on Biosorption Process}

The impact of initial $\mathrm{pH}$ was determined by the addition of $0.05 \mathrm{~g}$ of Azotobacter sp. to $20 \mathrm{~mL}$ of dye solution (50 $\mathrm{mg} . \mathrm{L}^{-1}$ ) at different $\mathrm{pH}$ solutions ranging from 3 to 7 . The remaining $\mathrm{MG}$ concentrations were determined at adsorptive equilibrium time.
Biosorption equilibrium studies were performed by the addition of $0.05 \mathrm{~g}$ of Azotobacter sp. in a series of Erlenmeyer flasks containing $20 \mathrm{~mL}$ of $\mathrm{MG}$ solution of different concentrations $\left(50,100,200,300,400 \mathrm{mg} . \mathrm{L}^{-1}\right)$ at $30^{\circ} \mathrm{C}$. A shaking was provided for $12 \mathrm{~h}$, to reach equilibrium. After equilibrium, the concentrations in the samples were determined as mentioned before.

Malachite green uptake: The amount of adsorbed dye onto the unit weight of adsorbent (Azotobacter sp.), qe (mg.g ${ }^{-1}$ ) was estimated using the mass balance equation given by:

$$
\mathrm{qe}(\mathrm{mg} / \mathrm{g})=(\mathrm{C} 0-\mathrm{Ce}) \mathrm{V} / \mathrm{M}
$$

where $\mathrm{C} 0$ and $\mathrm{Ce}$ represent the concentrations of $\mathrm{MG}$ $\left(\mathrm{mg} . \mathrm{L}^{-1}\right)$ in the solution at time, $\mathrm{t}=0$ and at any time $\mathrm{t}(\mathrm{h})$, respectively.

\section{RESULTS AND DISCUSSION}

\section{Effect of pH on Biosorption of Malachite Green}

The initial $\mathrm{pH}$ results in Fig. 1 show that the maximum adsorption capacity $\left(34.88 \mathrm{mg} . \mathrm{g}^{-1}\right.$ ) was recorded at $\mathrm{pH} 6.0$ while the minimum biosorption capacity $\left(1.5 \mathrm{mg} \cdot \mathrm{g}^{-1}\right)$ was determined at $\mathrm{pH} 2.0$.

Functional groups that are found in the cell wall of Azotobacter sp. are carboxyl, sulfate, and amine. At low $\mathrm{pH}$ solutions, the protonation of functional groups enhances a net positive charge on Azotobacter sp. This allows the electrostatic repulsion of malachite green dye molecules that are positively charged (cationic groups) which consequently, led to a decrease in the malachite green removal (Sekhar et al. 2009; Nath \& Ray 2015). On the other hand, at higher pH, the cell wall of bacteria was negatively charged which enhance the electrostatic attraction force between the cell wall and cationic dyes. So, the adsorption capacity increased from 7.5 $\mathrm{mg} . \mathrm{g}^{-1}$ to $34.88 \mathrm{mg} \cdot \mathrm{g}^{-1}$ at $\mathrm{pH}$ from 3-6.

A similar result was reported for biosorption of malachite green on Pithophora sp. at $\mathrm{pH} 6.0$ (studied in the range 2.0-7.0), biomass load $0.03 \mathrm{~g} / 30 \mathrm{~mL}$, and initial dye concentration up to $100 \mathrm{mg} . \mathrm{L}^{-1}$ within $5 \mathrm{~h}$ (Kumar et al. 2006). Nath and Ray (2015) and Jasińska et al. (2013) reported maximum biosorption of malachite green on $0.5 \mathrm{~g} . \mathrm{L}^{-1}$ of Bacillus cereus M116 (MTCC 5521) at pH 5.0.

\section{Effect of the Contact Time and the Initial Malachite Green Concentration}

In the present study, initial dye concentration varied from 50,100 , and $300 \mathrm{mg} . \mathrm{L}^{-1}$ up to contact time of $600 \mathrm{mins}$ using $0.05 \%$ biomass concentration at $30^{\circ} \mathrm{C}$ and $120 \mathrm{rpm}$. The adsorption rate increased gradually from 30 mins to 360 mins. 


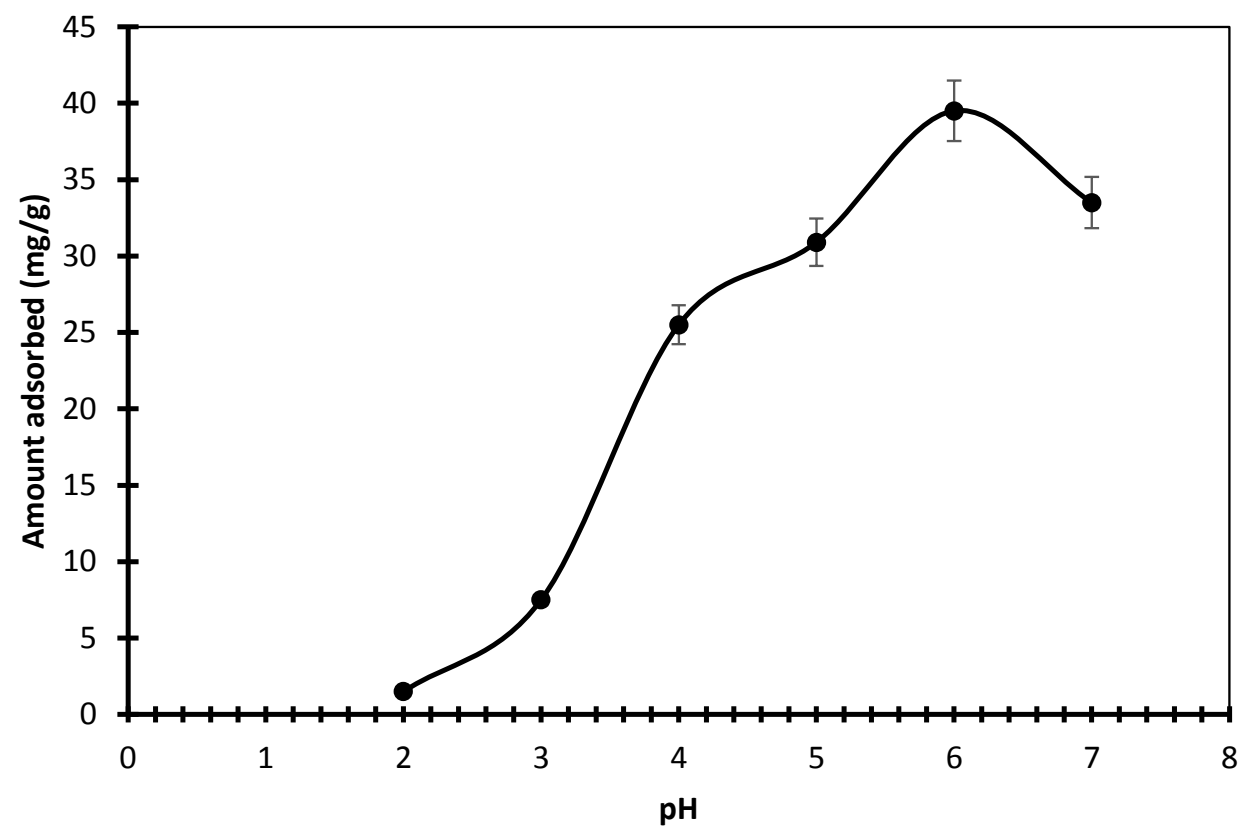

Fig. 1: Effect of $\mathrm{pH}$ on surface charge of Azotobacter sp. and on amount adsorbed (mg. $\mathrm{g}^{-1}$ ) of malachite green by Azotobacter sp. (volume of dye solution: $50 \mathrm{~mL}$; biomass concentration: $0.05 \%$; initial dye concentration: $50 \mathrm{mg} . \mathrm{L}^{-1}$; temperature: $30^{\circ} \mathrm{C}$; incubation time: $10 \mathrm{~h}$; shaking speed: $150 \mathrm{rpm}$ )

The biosorption rate reached saturation after 360 mins as illustrated in Fig. 2. The results exhibited that the equilibrium capacity of dye was $38.6 \mathrm{mg} . \mathrm{g}^{-1}, 81.3 \mathrm{mg} \cdot \mathrm{g}^{-1}$, and 112.6 $\mathrm{mg} \cdot \mathrm{g}^{-1}$ that were determined when the initial concentration of dye was 50,100 , and $300 \mathrm{mg} . \mathrm{L}^{-1}$, respectively.

The cell surface of Azotobacter sp. consists of a large number of negatively charged functional groups which serve as active sites for adsorption of positively charged cationic dyes. This explains the reason for the rapid biosorption rate at the initial period. After a lapse of time, all active sites were occupied with dye molecules and became saturated. So, any additional particles of dyes would encourage a repulsion force between the external adsorbed layer of dye on the adsorbent's active sites and the added one (Mawad et al. 2014).

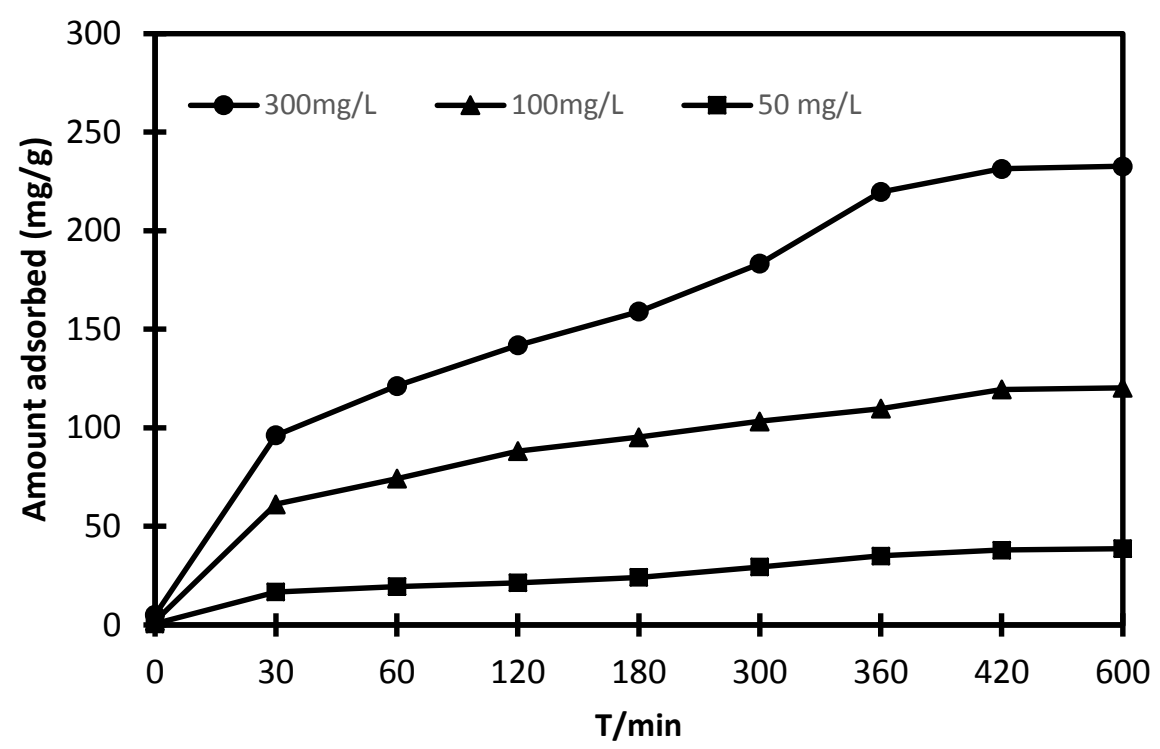

Fig. 2.: Impact of contact time and initial dye concentration on adsorption of malachite green $(50 \mathrm{~mL})$ by Azotobacter sp. $(0.05 \%)$ at $30^{\circ} \mathrm{C}$; shaking speed: $150 \mathrm{rpm}$. 


\section{Biosorption Kinetics}

The investigation of batch biosorption kinetics provides information for designing batch sorption systems. Adsorption kinetics clarify the speed of the adsorption process. The kinetics of solute uptake gives information about the optimum operating conditions for a full-scale batch process (Kim \& Choi 2017). Many kinetic models have been established to describe the reaction order of the adsorption process that represents the experimental data. In this study, the kinetics experiments were achieved at the optimum $\mathrm{pH}$ value (6.0) and initial dye concentrations of 50,100, 200,300, and $400 \mathrm{mg}$. $\mathrm{L}^{-1}$; the kinetics parameters of adsorption were determined by pseudo-first-order which is expressed as (Töwe et al. 2007)

$$
\log (\mathrm{qe}-\mathrm{qt})=\log \mathrm{e}-\mathrm{K} 1 \mathrm{t} / 2.303
$$

where $\mathrm{k} 1$ is the pseudo-first-order rate constant and qe and qt are the adsorption capacity of the dye molecules on adsorbent at equilibrium and at time $\mathrm{t}$, respectively. The values of $\mathrm{k} 1$ and qe were estimated by plotting $\log (\mathrm{qe}-\mathrm{qt})$ versus the time (Fig.3a). The calculated qe is demonstrated in Table 1 when the initial concentrations were 50, 100, and $300 \mathrm{mg} . \mathrm{L}^{-1}$, the theoretical values of qe of MG were $2.5,1.5$, and $1.6 \mathrm{mg}_{\mathrm{g}} \mathrm{g}^{-1}$, the $\mathrm{R}^{2}$ values of the plots were $0.98,0.87$, and 0.97 , and the values of $\mathrm{k} 1$ were $0.0045,0.0034$ and 0.0035 , respectively. The results showed that the calculated qe values seemed to be much lower than the experimental values of $38.4,81.2$, and 112.8, when the initial concentrations were 50, 100, and $300 \mathrm{mg} . \mathrm{L}^{-1}$. respectively (Fig.3a).

The linear form of the pseudo-second-order kinetics model (Ho \& McKay 1999) was represented by the equation

$$
\mathrm{t} / \mathrm{q}_{\mathrm{t}}=1 / \mathrm{k}_{2} \mathrm{qe}^{2}+\mathrm{t} / \mathrm{q}_{\mathrm{e}}
$$

Where $k_{2}$ is the pseudo-second-order adsorption rate constant. The values of $\mathrm{k}_{2}$ and $\mathrm{q}_{\mathrm{e}}$ were estimated from the slope and intercept of the plots of t/qe versus $t$ at different concentrations of 50,100, and $300 \mathrm{mg} . \mathrm{L}^{-1}$ of MG (Fig. 3b).

It was observed that the values of $\mathrm{R}^{2}$ were $0.96,0.99$, and 0.95 while the values of $\mathrm{K}_{2}$ were $8.6 \times 10^{-5}, 1.1 \times 10^{-4}$, and $2.7 \times 10^{-5}$ for biosorption of 50,100 , and $300 \mathrm{mg} . \mathrm{L}^{-1}$ of $\mathrm{MG}$, respectively. Moreover, the theoretical amount adsorbed (qe) were 40.3, 83.2, and $120.2 \mathrm{mg} . \mathrm{g}^{-1}$ (Table 1).

In most studied adsorption systems, the pseudo-first-order model does not fit well over the entire adsorption stage and is generally applicable for the very early stage of the adsorption process. The pseudo-second-order model can expect the sorption attitude along with the whole-time adsorption (Ho 2006). The pseudo-second-order kinetics model is based on the adsorption capacity of the solid phase and confirms the chemisorption process.

\begin{tabular}{|c|c|c|c|c|c|c|}
\hline & \multicolumn{3}{|c|}{ Pseudo-first-order } & \multicolumn{3}{|c|}{ Pseudo-second-order } \\
\hline Adsorbate $\left(\mathrm{mg} \cdot \mathrm{L}^{-1}\right)$ & $\mathrm{q}_{\mathrm{e}}\left(\mathrm{mg} \cdot \mathrm{g}^{-1}\right)$ & $\mathrm{K}_{1}\left(\min ^{-1}\right)$ & $\mathrm{R}^{2}$ & $\begin{array}{l}\mathrm{q}_{\mathrm{e}} \\
\left(\mathrm{mg} \cdot \mathrm{g}^{-1}\right)\end{array}$ & $\begin{array}{l}\mathrm{K}_{2} \\
\left(\mathrm{gmg} \cdot \mathrm{min}^{-1}\right)\end{array}$ & $\mathrm{R}^{2}$ \\
\hline 50 & 2.5 & 0.004 & 0.98 & 40.1 & $8.6 \times 10^{-5}$ & 0.96 \\
\hline 100 & 1.2 & 0.004 & 0.87 & 38.2 & $1.1 \times 10^{-4}$ & 0.99 \\
\hline 400 & 6.7 & 0.036 & 0.95 & 120.2 & $2.7 \times 10^{-5}$ & 0.96 \\
\hline
\end{tabular}

Table 1: Kinetic parameters for adsorption of malachite green on Azotobacter sp.
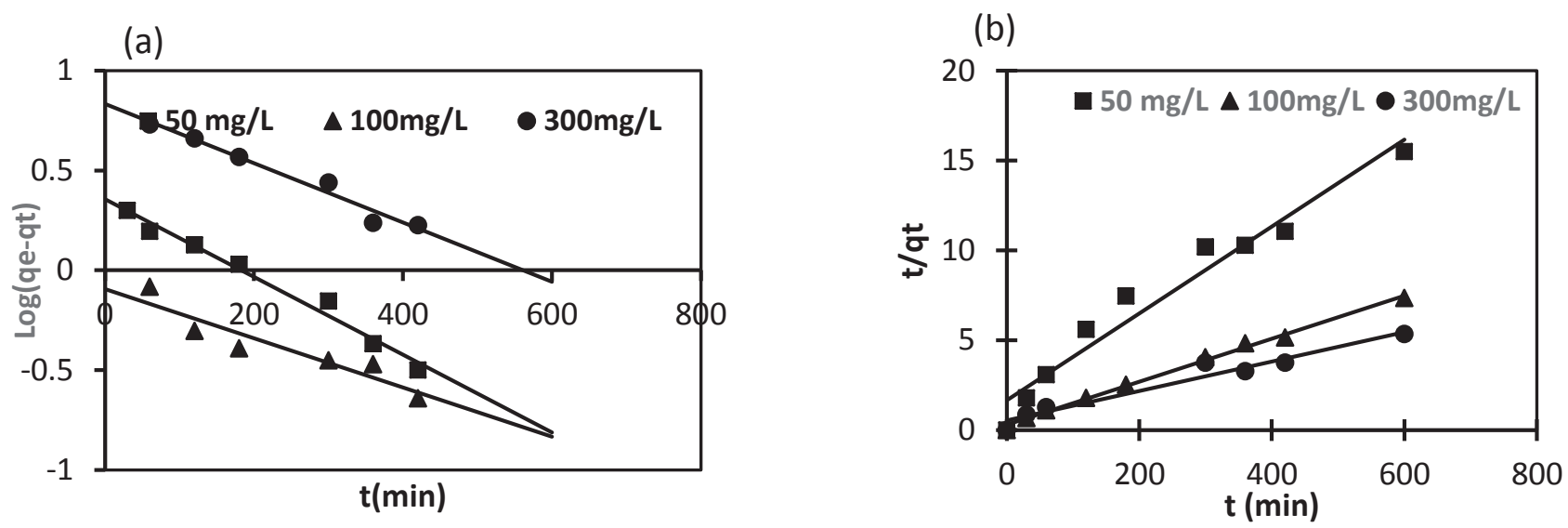

Fig. 3: (a) Pseudo first order (b) pseudo-second-order kinetic plot for adsorption of malachite green by Azotobacter sp.. 
The results of pseudo-second-order depicted that the $\mathrm{R}^{2}$ values were close to 1.0 and the theoretical qe $\left(\mathrm{mg}_{\mathrm{g}} \mathrm{g}^{-1}\right)$ was close enough to the experimental values. So, the most suitable model to describe the biosorption of malachite green by Azotobacter sp. is the pseudo-second-order kinetic model. Moreover, the obtained results suggested the chemisorption behavior of malachite green on the surface of Azotobacter sp. as it followed the pseudo-second-order model. These results came in the context of much literature that discussed the absorption kinetics of malachite green by microorganisms (Jasińska et al. 2013; Nath \& Ray 2015).

\section{Equilibrium Adsorption Isotherms}

Adsorption isotherm is requested in the study of biosorption because it provides the description of the stoichiometric solute-solid interaction (Das \& Guha 2007). Biosorption equilibrium gives the essential physiochemical information for evaluating the applicability of the sorption process as a unit operation (Nath \& Ray 2015) as shown in Fig. 4. To investigate the adsorbate-adsorbent interaction, the adsorption equilibrium data was analyzed by Langmuir (Langmuir 1918) and Freundlich (Freundlich 1906) isotherm models as shown in equations (4) and (5), respectively.

$$
\begin{aligned}
& \text { Ceq/qe }=1 / \text { maxb+ceq/qmax } \\
& \text { Lnqeq }=(1 / n) \text { lnceq }+ \text { lnkf }
\end{aligned}
$$

Where $b$ is the Langmuir constant $\left(\mathrm{dm}^{3} \cdot \mathrm{mg}^{-1}\right)$ related to the affinity between adsorbate and adsorbent and qmax is the maximum monolayer adsorption capacity (mg.g ${ }^{-1}$ ). $\mathrm{K}_{\mathrm{f}}$ $\left(\mathrm{dm}^{3} \cdot \mathrm{g}^{-1}\right)$ and $\mathrm{n}$ are the adsorption capacity and the intensity of adsorption, respectively.
The Langmuir isotherm is valid for monolayer adsorption onto a surface with a finite number of identical sites. Langmuir's equation proposed that the surface is homogenous. If the experimental data fitted to the Langmuir isotherm model, it indicates the monolayer coverage of solute onto the adsorbent surface and the homogenous distribution of solute on active sites. On the other hand, Freundlich isotherm proposed that the adsorption process performs on heterogeneous surfaces and considers the multilayer adsorption phenomenon (Nath \& Ray 2015).

Results in Fig. 4 show the adsorption equilibrium plot of malachite green. Isotherm model parameters were estimated from the slope and intercept of their respective equilibrium plots (Fig. 5a \& 5b). The values of isotherm parameters and linear regression correlation coefficient $\left(\mathrm{R}^{2}\right)$ for the two isotherm models have been summarized in Table 2. Based on linear regression correlation coefficient $\left(\mathrm{R}^{2}\right)$ values of the two isotherm models, results were found to be described best by Langmuir (Fig. 5a). These observations indicate that the adsorption mechanism is a hybrid one and does not follow the ideal monolayer adsorption behavior. These results were in accordance with the results of biosorption of malachite green by Bacillus cereus (Kumar et al. 2005; Pan et al. 2006; Dahri et al. 2014).

\section{CONCLUSION}

Malachite green is a toxic triphenylmethane dye that is still being used in many countries. Azotobacter sp. is known to play a viable role in atmospheric nitrogen fixation and fertility of the soil. This study is considered the first that

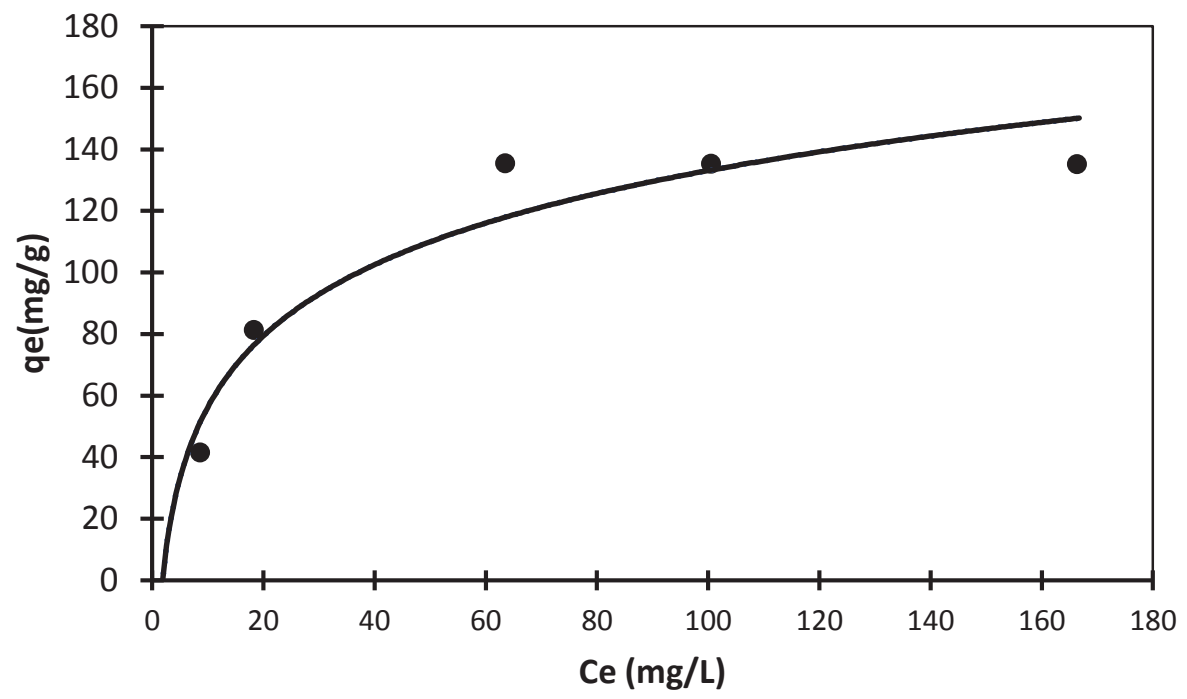

Fig. 4: Equilibrium adsorption isotherm for adsorption of malachite green by Azotobacter sp.. 
Table 2: Equilibrium adsorption isotherm constants for the fitted isotherm models

\begin{tabular}{|c|c|c|c|c|c|}
\hline \multicolumn{3}{|c|}{ Langmuir } & \multicolumn{3}{|l|}{ Freundlich } \\
\hline $\mathrm{Q}_{\max }$ & $\mathrm{b}\left(\mathrm{L} \cdot \mathrm{mg}^{-1}\right)$ & $\mathrm{R}^{2}$ & $\mathrm{~K}_{\mathrm{F}}\left(\mathrm{mg} \cdot \mathrm{g}^{-1}\right)$ & $\mathrm{n}$ & $\mathrm{R}^{2}$ \\
\hline 141.2 & 0.45 & 0.99 & 13803.1 & 0.5 & 0.92 \\
\hline
\end{tabular}
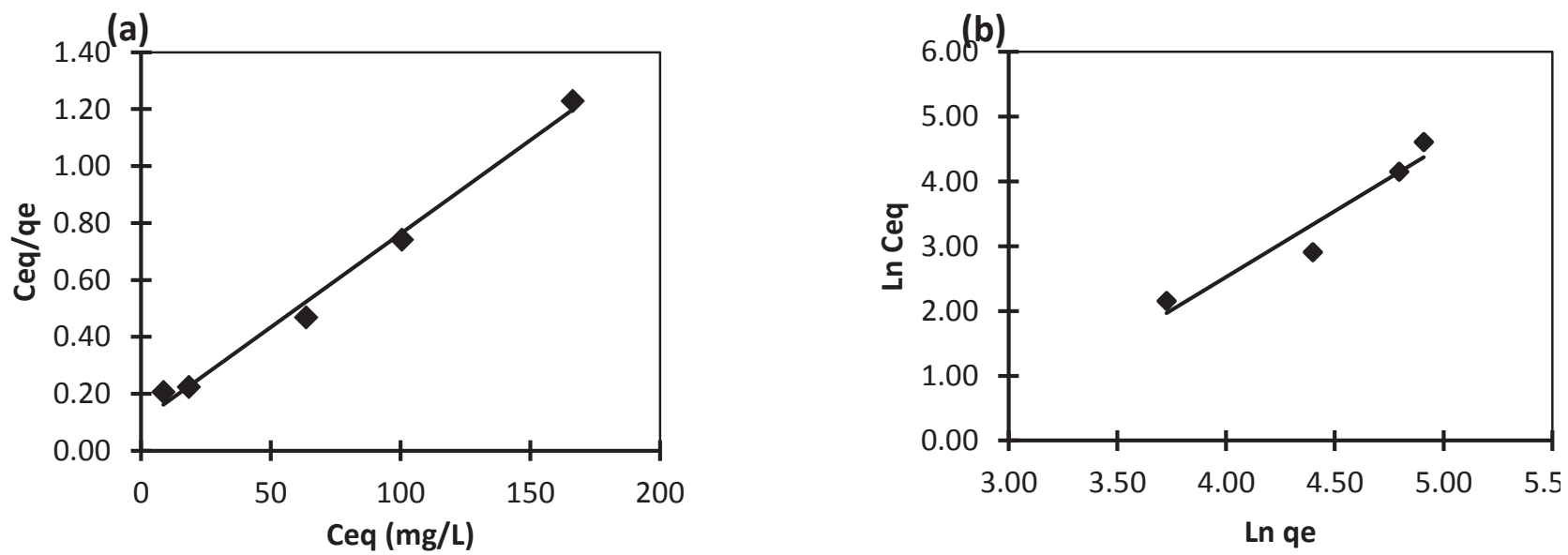

Fig. 5: Langmuir (a) and Freundlich (b) isotherm plots at $30^{\circ} \mathrm{C}$ (volume of dye solution: $50 \mathrm{~mL}$; biomass concentration: $0.05 \%$; temperature: $30^{\circ} \mathrm{C}$; incubation time: $10 \mathrm{~h}$; shaking speed: $150 \mathrm{rpm})$.

discussed the role of Azotobacter biomass in the biosorption of toxic dyes from the aquatic environment. The biomass of Azotobacter sp. is characterized by low cost and easy to be provided without any toxic constraints. In this study, Azotobacter exhibited an efficient adsorption capacity of malachite green within 360 mins.

\section{REFERENCES}

Adhikari, S., Chattopadhyay, P. and Ray, L. 2010. Biosorption of malathion by dry cells of an isolated Bacillus sp. S14. Chem. Speciat. Bioavailab., 22: 207-213.

Cha, C.J., Doerge, D.R. and Cerniglia, C.E. 2001. Biotransformation of malachite green by the fungus Cunninghamella elegans. App. Env. Microbiol., 67: 4358-4360.

Culp, S.J. and Beland, F.A. 1996. Malachite green: A toxicological review. J. Am. Coll. Toxicol., 15: 219-238.

Dahri, M.K., Kooh, M.R.R. and Lim, L.B. 2014. Water remediation using a low-cost adsorbent walnut shell for removal of malachite green: Equilibrium, kinetics, thermodynamic and regeneration studies. J. Environ. Chem. Eng., 2: 1434-1444.

Das, S.K. and Guha, A.K. 2007. Biosorption of chromium by Termitomyces clypeatus. Colloids Surf. B-Biointerfaces, 60: 46-54.

Dos Santos, A.B., Cervantes, F.J. and van Lier, J.B. 2007. Review paper on current technologies for decolorization of textile wastewaters: Perspectives for anaerobic biotechnology. Bioresour. Technol., 98: 2369-2385.

Erdem, E., Çölgeçen, G. and Donat, R. 2005. The removal of textile dyes by diatomite earth. J. Colloid Interface Sci., 282: 314-319.

Freundlich, U. 1906. On adsorption in solutions. J. Phys. Chem., 57: 385-470.
Gao, R., Geng, Y., Li, G., Gu, Y. and Qian, S. 2017. Influence of tourmaline on DPC pore structure and removal effect on the malachite green. Nat. Environ. Pollut. Technol., 16(2): 667.

Gouranchat, C. 2000. Malachite green in fish culture (state of the art and perspectives): Bibliographic study. Ecole Natl. Veterinaire, 142: 2000.

Gupta, V.K. and Saleh, T.A. 2013. Sorption of pollutants by porous carbon, carbon nanotubes and fullerene: An overview. Environ. Sci. Pollut. Res. Int., 20: 2828-2843.

Ho, Y.S. 2006. Review of second-order models for adsorption systems. J. Hazard. Mater., 13: 681-689.

Ho, Y.S. and McKay, G.1999. Pseudo-second order model for sorption processes. Process Biochem., 34: 451-465.

Inyinbor, A., Dada, O.A., Bello, O.S., Oluyori, A.P., Fanawopo, O.F., Oreofe, T.A. and Ajayi, O. 2020. Surface modified low-cost adsorbent in malachite green scavenging, malachite green/rhodamine $\mathrm{B}$, and malachite green/rhodamine b/Cu2 + composite treatment. Orbital: E-J. Chem., 12: 87-94.

Jasińska, A., Bernat, P. and Paraszkiewicz, K. 2013. Malachite green removal from aqueous solution using the system rapeseed press cake and fungus Myrothecium roridum. Desal. Water. Treat., 51: 7663-7671.

Kim, S.H. and Choi, P.P. 2017. Enhanced Congo red dye removal from aqueous solutions using iron nanoparticles: adsorption, kinetics, and equilibrium studies. Dalton Trans., 46: 15470-15479.

Kumar, K.V., Ramamurthi, V. and Sivanesan, S. 2006. Biosorption of malachite green, a cationic dye onto Pithophora sp., freshwater algae. Dyes Pigm., 69: 102-107.

Kumar, K.V., Sivanesan, S. and Ramamurthi, V. 2005 Adsorption of malachite green onto Pithophora sp., freshwater algae: Equilibrium and kinetic modeling. Process. Biochem., 40: 2865-2872.

Langmuir, I. 1918 The adsorption of gases on plane surfaces of glass, mica and platinum. J. Am. Chem. Soc., 40: 1361-1403. 
Liu, J., Zhang, L., Zha, D., Chen, L., Chen, X. and Qi, Z. (2018) Biosorption of malachite green onto Haematococcus pluvialis observed through synchrotron Fourier-transform infrared microspectroscopy. Lett. Appl. Microbiol., 67: 348-353.

Mawad, A., Yousef, N. and Shoreit, A. 2014. Bioremediation of acid blue 25 dye by anthracene degrading Pseudomonas pseudoalcaligenes ASU-016. Int. J. Environ. Sci. (CAT), 10: 27-34.

Mawad, A.M., Abd Hesham, E.L., Yousef, N.M., Shoreit, A.A., Gathergood, N. and Gupta, V.K. 2020. Role of bacterial-fungal consortium for enhancement in the degradation of industrial dyes. Curr. Genomics, 21: 283-294.

Mawad, A.M., Yousef, N.M. and Shoreit, A.A. 2016. Robust Aspergillus terreus biofilm supported on graphene oxide/hematite-nanocomposites for adsorption of anthraquinone dye. Desalin. Water Treat., 57: 24341-24351.

Nath, J. and Ray, L. 2015. Biosorption of malachite green from aqueous solution by dry cells of Bacillus cereus m116 (MTCC 5521). J. Environ. Chem. Eng., 3: 386-394.

Nemerow, N.L. 1963. Theories and practices of industrial waste treatment. J. Amer. Water Resour., 4(4): 66-67
Pan, J., Ge, X., Liu, R. and Tang, H. 2006. Characteristic features of Bacillus cereus cell surfaces with biosorption of $\mathrm{Pb}$ (II) ions by AFM and FT-IR. Colloids Surf. B Biointerfaces, 52: 89-95.

Schnick, R.A. 1988. The impetus to register new therapeutants for aquaculture. Prog. Fish-Cult., 50: 190-196.

Sekhar, C.P., Kalidhasan, S., Rajesh, V. and Rajesh, N. 2009. Bio-polymer adsorbent for the removal of malachite green from an aqueous solution. Chemosphere, 77: 842-847.

Srivastava, S., Sinha, R. and Roy, D. 2004. Toxicological effects of malachite green. Aquat. Toxicol., 66: 319-329.

Töwe, S., Leelakriangsak, M., Kobayashi, K., Van Duy, N., Hecker, M., Zuber, P. and Antelmann, H. 2007. The MarR-type repressor MhqR (YkvE) regulates multiple dioxygenases/glyoxalases and an azoreductase which confer resistance to 2-methylhydroquinone and catechol in Bacillus subtilis. Mol. Microbiol., 66: 40-54.

Wu, L., Xu, Z., Meng, Q., Xiao, Y., Cao, Q., Rathi, B., Liu, H., Han, G., Zhang, J. and Yan, J. 2020. A new aptamer/black phosphorus interdigital electrode for malachite green detection. Anal. Chim. Acta., 1099: 39-45. 